\begin{tabular}{|c|c|c|c|c|}
\hline $\begin{array}{c}\text { 118SHARE: SOCIAL WORK } \\
\text { JURNAL }\end{array}$ & VOLUME: 7 & NOMOR: 1 & HALAMAN: $1-129$ & $\begin{array}{l}\text { ISSN:2339 -0042 }(p) \\
\text { ISSN: 2528-1577 }(e)\end{array}$ \\
\hline
\end{tabular}

\title{
PERAN PEMBIMBING KEMASYARAKATAN DALAM PENANGANAN ANAK BERKONFLIK DENGAN HUKUM OLEH BALAI PEMASYARAKATAN
}

\author{
Oleh: \\ Meilanny Budiarti $S^{1}$. dan Rudi S. Darwis ${ }^{2}$ \\ 1. Pusat Studi Kesejahteraan Anak dan Keluarga FISIP- Unpad \\ 2. Pusat Studi Kewirausahaan Sosial, CSR dan Pengembangan Masyarakat FISIP-Unpad \\ Email: \\ (meilannybudiarti13@gmail.com; rsdarwis@unpad.ac.id)
}

\begin{abstract}
Abstrak
Penanganan Anak Yang Berkonflik Dengan Hukum (ABH) tidak dapat dilakukan seperti terhadap orang dewasa. Balai Pemasyarakatan (BAPAS), melalui peran Pendamping Kemasyarakatan yang dimilikinya, berperan penting dalam proses peradilan $\mathrm{ABH}$ sesuai dengan peraturan perundanganundangan yang berlaku. Pada tulisan ini akan dipaparkan pelaksanaan peran dari Pendamping Kemasyarakatan (PK) dalam menjalankan fungsi BAPAS pada penanganan $\mathrm{ABH}$.

Metode yang digunakan dalam kajian ini adalah metode penelitian deskriptif dengan pendekatan kualitatif guna mencermati perilaku, tindakan, lingkungan sosial serta aspek lainnya yang terkait dengan pelaksanaan peran (PK) pada setiap tahap dalam proses peradilan yang dijalani oleh $\mathrm{ABH}$, yaitu pada tahap sebelum pengadila (pra-adjudikasi), tahap pengadilan (adjudikasi), dan tahap setelah pengadilan (post-adjudukasi).

Hasil penelitian menunjukan bahwa PK tidak dapat melakukan pendampingan secara penuh sebagaimana mestinya kepada $\mathrm{ABH}$ yang menjalani proses peradilan. Hal ini antara lain disebabkab oleh keterbatasan jumlah PK yang dimiliki BAPAS sehingga seorang PK harus mendampingi beberapa orang $\mathrm{ABH}$ yang seringkali lokasinya berjauhan dengan waktu yang terbatas. Meskipun demikian, fungsi BAPAS dalam proses penanganan $\mathrm{ABH}$ dapat dijalankan sesuai tahapan yang ditetapkan. BAPAS dapat menjalankan fungsi sebagai lembaga yang menangani ABH berbeda dengan cara penanganan orang dewasa, sesuai perundangan-undangan.
\end{abstract}

Kata Kunci: anak berkonflik dengan hukum, balai pemasyarakatan, pembimbing kemasyarakatan 


\section{Pendahuluan}

Di Indonesia masalah Anak yang berkonflik dengan hukum mempunyai kecenderungan semakin meningkat. Catatan kriminalitas terkait Anak di Indonesia seperti yang diungkapkan oleh Direktur Bimbingan Kemasyarakatan dan Pengentasan Anak Ditjen Pemasyarakatan menunjukkan data bahwa anak-anak yang berada di lingkungan rutan dan lapas berjumlah 3.812 orang. Anak-anak yang diversi sebanyak 5.229 orang, dan total sekitar 10 ribu Anak termasuk mereka yang sedang menjalani asimilasi, pembebasan bersyarat dan cuti jelang bebas ${ }^{33}$ (Priyadi, 2015). Data tersebut menunjukkan jumlah Anak yang berkonflik di Indonesia cukup banyak.

Bartollas (1985) mengemukakan ada beberapa faktor yang menjadi latar belakang karakteristik pribadi anak yang berisiko tinggi menjadi pelaku delinquency, yaitu faktor umur (anak yang lebih muda akan berisiko lebih tinggi), variable psikologis (sifat membantah, susah diatur, merasa kurang dihargai), school performance (bermasalah di sekolah dengan tingkah lakunya, membolos), home adjustment (kurang interaksi dengan orang tua dan saudara, kurang disiplin dan pengawasan, minggat), pengguna alkohol dan obat terlarang, lingkungan tetangga, dan adanya pengaruh kekuatan teman sebaya ${ }^{34}$ (Marlina, 2009).

Terkait kondisi psikologi anak, negara mengeluarkan instrumen-instrumen hukum agar membedakan perlakuan hukum terhadap anak salah satunya ialah Undang-undang No.11 tahun 2012 tentang Sistem Peradilan Pidana Anak. Sejalan dengan semangat undang-undang tersebut, Pekerja Sosial koreksional menjalankan proses membantu dan merehabilitasi anak yang mempunyai masalah pelanggaran hukum. Pelayanan

\footnotetext{
$33 \quad$ http://www.pikiran-rakyat.com/bandungraya/2015/08/04/337054/sepuluh-ribu-anak-kiniberhadapan-dengan-hukum
}

pekerjaan sosial koreksional tidak didasarkan kepada upaya balas dendam atau hukuman tetapi lebih menitikberatkan kepada upaya professional dalam rangka memperbaiki dan meningkatkan kemampuan berfungsi sosial klien, sehingga dikemudian hari klien dapat berinteraksi sosial dalam masyarakat dan melaksanakan tugas-tugas kehidupannya kembali.

\section{Balai Pemasyarakatan (BAPAS)} adalah salah satu pihak yang terlibat selama proses peradilan Anak yang berkonflik dengan hukum dari awal anak ditangkap hingga anak menyelesaikan masa hukumannya. Hal ini membuat BAPAS memiliki peran yang penting dalam proses peradilan Anak yang berkonflik dengan hukum. Secara umum peran BAPAS dalam proses peradilan Anak yang berkonflik dengan hukum terbagi menjadi 3 tahap, yaitu tahap sebelum sidang pengadilan (pra adjudikasi) yakni penyidikan, tahap saat sidang pengadilan (adjudikasi) yakni pendampingan di persidangan dan tahap setelah pengadilan (post adjudikasi) yakni pengawasan dan pembimbingan bagi Anak yang berkonflik dengan hukum ${ }^{35}$ (Nashriana, 2012: 110-116).

Pelaksanaan proses peradilan Anak yang berkonflik dengan hukum cenderung tidak sesuai dengan Undang-undang atau hukum yang mengikat para institusi khususnya BAPAS. Hal ini terlihat dari hasil pemantauan oleh Komisi Perlindungan Anak Indonesia (KPAI) pada tahun 2012 terhadap beberapa BAPAS yang ada di Indonesia. KPAI mendapatkan laporan bahwa terdapat beberapa penyimpangan seperti mayoritas anak tidak didampingi penasehat hukum dan pembimbing kemasyarakatan (BAPAS) selama proses di peradilan, mayoritas putusan hakim pidana penjara, banyak hak anak yang terampas selama proses peradilan, diantaranya hak pendidikan, hak kesehatan, hak untuk berkreasi, dan anak jalanan yang menjadi Anak

\footnotetext{
34 Marlina, Peradilan Pidana Anak di Indonesia Pengembangan Konsep Diversi dan Restorative Justice (Bandung: Refika Aditama, 2009)

${ }^{35}$ Nashriana. 2012. Perlindungan Hukum Pidana Bagi Anak Di Indonesia. Depok: RajaGrafindo Persada
} 
yang berkonflik dengan hukum seringkali ditahan karena tidak ada yang menjamin ${ }^{36}$

Pelaksanaan proses peradilan Anak yang berkonflik dengan hukum cenderung tidak sesuai dengan Undang-undang atau hukum yang mengikat para institusi khususnya BAPAS. Hal ini terlihat dari hasil pemantauan oleh Komisi Perlindungan Anak Indonesia (KPAI) pada tahun 2012 terhadap beberapa BAPAS yang ada di Indonesia. KPAI mendapatkan laporan bahwa terdapat beberapa penyimpangan seperti mayoritas anak tidak didampingi penasehat hukum dan pembimbing kemasyarakatan (BAPAS) selama proses di peradilan, mayoritas putusan hakim pidana penjara, banyak hak anak yang terampas selama proses peradilan, diantaranya hak pendidikan, hak kesehatan, hak untuk berkreasi, dan anak jalanan yang menjadi Anak yang berkonflik dengan hukum seringkali ditahan karena tidak ada yang menjamin ${ }^{3738}$

Pemaparan-pemaparan tersebut menunjukkan bahwa masih kuranganya penanganan yang diberikan kepada anak yang berkonflik dengan hukum. Fenomena ini memicu munculnya fenomena-fenomena lainnya yang berdampak kepada tumbuh kembang anak selanjutnya. Seperti yang dijelaskan oleh Sambas (2013:35) bahwa Anak berkonflik dengan hukum yang melewati tahapan-tahapan pengadilan tanpa kehadiran pendamping atau salah satunya BAPAS cenderung untuk terjerumus kembali kedalam pelanggarannya baik itu dengan kasus yang sama ataupun dengan kasus yang berbeda. Hal ini dikarenakan tidak adanya efek jera dari penanganan ataupun sebagai akibat dari penangan yang tidak tepat. Senada dengan pernyataan tersebut, Supeno (2010: 75) menyatakan bahwa anak yang pernah menjadi anak yang berkonflik dengan hukum, ketika kembali ke masyarakat tidak mendapatkan kepercayaan diri dan mudah putus asa. Situasi ini sering muncul karena anak yang telah

\footnotetext{
36 www.kpai.go.id/artikel/implementasi-restorasi-justicedalam-penanganan-anak-bermasalah-dengan-hukum, diakses pada Tgl. 17 Juni 2014

${ }^{37}$ Ibid.

38 Nandang Sambas,. Peradilan Pidana Anak di Indonesia dan Instrumen Internasional Perlindungan
}

melewati masa penahanan langsung dilepas begitu saja ke tengah masyarakat tanpa ada proses pengawasan lanjutan dari pihak yang berwajib. $^{39}$

\section{Metode}

Dalam kajian Penanganan Anak yang Berkonflik dengan Hukum oleh BAPAS ini, metode yang digunakan adalah metode penelitian deskriptif dengan pendekatan kualitatif guna mencermati perilaku, tindakan, lingkungan sosial serta aspek lainnya yang terkait dengan proses peradilan yang dijalani oleh Anak yang berkonflik dengan hukum.

Teknik penelitian yang digunakan adalah studi kasus karena topik mengenai penanganan Anak yang Berkonflik dengan Hukum ini terikat dan dibatasi oleh waktu tertentu yakni proses pada sebelum, saat dan setelah persidangan dan juga topik ini terikat oleh tempat penanganan Anak yang berkonflik dengan hukum yang dilakukan oleh BAPAS Kelas I Bandung.

Kasus yang dibahas dalam penelitian ini terdiri dari dua kasus $\mathrm{ABH}$, yakni Kasus A dan Kasus B. Kasus A merupakan jenis kasus yang paling banyak ditangani oleh BAPAS Kelas I Bandung pada setiap tahunnya, yakni kasus pencurian. Adapun kasus B adalah kasus pembunuhan sebagai kasus yang paling jarang ditangani oleh pihak BAPAS. Dalam hal teknik pengumpulan data, digunakan teknik wawancara secara mendalam (indepth interview), observasi dan studi kepustakaan.

\section{Pembahasan}

Proses penanganan Anak yang berkonflik dengan hukum dengan orang dewasa yang berkonflik dengan hukum tidak bisa disamakan karena keduanya memiliki sistem peradilan yang berbeda. Anak masih memerlukan bantuan dari orang dewasa untuk

Anak serta Penerapannya. (Yogyakarta: Graha Ilmu, 2013)

${ }^{39}$ Hadi Supeno, Kriminalisasi Anak: Tawaran Gagasan Radikal Peradilan Anak Tanpa Pemidanaan. (Jakarta: Gramedia Pustaka Umum, 2010) 
memenuhi kebutuhannya, menentukan pilihannya serta mendapatkan haknya.

Untuk mencapai pemahaman yang memadai terhadap pemikiran dalam penangan anak yang berkonflik dengan hukum, secara konseptual perlu diperhatikan tahapan dalam proses penanganan tersebut. Berdasarkan tahapan penanganan, maka proses penanganan anak yang berkonflik dengan hukum oleh BAPAS terdiri dari:

1) Proses Penanganan BAPAS Sebelum Pengadilan, yang berisi kegiatan pendampingan anak yang berkonflik dengan hukum, yang meliputi:

a. Proses pemberian informasi dan saran kepada pihak pengadilan mengenai anak dengan membacakan hasil Penelitian Masyarakat

b. Memfasilitasi kebutuhan dan informasi yang dibutuhkan oleh Anak yang berkonflik dengan hukum

c. Memfasilitasi kebutuhan dan informasi bagi keluarga Anak yang berkonflik dengan hukum.

d. Koordinasi dengan Pihak Pengadilan

e. Pemenuhan Hak-hak Anak saat Pengadilan

2) Proses Penanganan BAPAS Saat Pengadilan, yang berisi kegiatan penyusunan penelitian masyarakat (PPM) terhadap anak yang berkonflik dengan hukum, yang meliputi:
a. BAPAS melakukan wawancara kepada Anak yang berkonflik dengan hukum
b. Wawancara kepada pihak-pihak yang terkait dengan anak, seperti teman, keluarga atau guru.
c. Meneliti lingkungan tempat tinggal dan lingkungan sekolah anak
d. Koordinasi dengan Pihak Kepolisian
e. Pemenuhan Hak-hak Anak Sebelum Pengadilan

3) Proses Penanganan BAPAS Setelah Pengadilan, yang terdiri dari proses pembingan dan proses pengawasan. Proses Pembingan meliputi:
a. Melakukan Bimbingan Kelompok
b. Melakukan
Bimbingan Ketrampilan
c. Melakukan Bimbingan Perorangan
d. Pemenuhan Hak-hak Anak setelah Pengadilan.

Untuk menggambarkan pelaksanaan penanganan kasus ABH di BAPAS Kelas I Bandung, berikut akan diuraikan proses penanganan yang dilakukan terhadap A (16 Tahun) dan B (15 Tahun). A merupakan anak yang berkonflik dengan hukum dengan kasus pencurian motor. A seorang anak laki-laki, berusia 16 tahun dan sedang duduk di bangku SMA di sebuah sekolah swasta. Kasus A ini terjadi pada saat ia berusia 14 tahun. A dibimbing oleh Pembimbing Kemasyarakatan sejak ia ditangkap polisi, saat menjalani 3 kali proses pengadilan, pada masa Cuti Bersyarat dan pada saat Bimbingan Lanjutan (After Care). A melakukan laporan kepada BAPAS Kelas I Bandung secara berkala selama masa cuti bersyarat, yakni satu kali dua minggu selama 3 (tiga) bulan. A mengikuti dua kali bimbingan keterampilan dan satu kali bimbingan kelompok.

Kasus yang kedua adalah B, yakni anak yang berkonflik dengan hukum untuk kasus pembunuhan. Anak Perempuan ini berusia 15 tahun dan pendidikan terakhirnya ialah SMP (Sekolah Menengah Pertama) kelas 3. B tinggal bersama orangtuanya. B ditangani oleh seorang pembimbing kemasyarakatan sebagai perwakilan dari BAPAS. Pada saat B telah menyelesaikan masa tahanannya dan mengikuti masa Pembebasan Bersyarat, B merasa bahwa ia tidak mendapatkan perhatian dari pembimbing kemasyarakatan sebagaimana yang diharapkannya sehingga ia meminta agar pembimbingnya diganti. Oleh karena itu pada masa Pembebasan Bersyarat, pembimbingan B dialihkan kepada pembimbing lainnya. Sejak saat itu ia rajin berkomunikasi dengan pembimbing barunya. Dalam kurun waktu tiga bulan, B menjalani 3 (tiga) kali bimbingan kelompok dan dua diantaranya adalah berupa bimbingan keterampilan. 


\begin{tabular}{|c|c|c|c|c|}
\hline $\begin{array}{c}\text { 118SHARE: SOCIAL WORK } \\
\text { JURNAL }\end{array}$ & VOLUME: 7 & NOMOR: 1 & HALAMAN: 1 - 129 & $\begin{array}{l}\text { ISSN:2339 -0042 }(p) \\
\text { ISSN: 2528-1577 }(e)\end{array}$ \\
\hline
\end{tabular}

Tabel 1

Penanganan BAPAS Pada Kasus A dan Kasus B

\begin{tabular}{|c|c|c|}
\hline $\begin{array}{c}\text { Penanganan } \\
\text { BAPAS }\end{array}$ & Kasus A & Kasus B \\
\hline $\begin{array}{l}\text { Sebelum } \\
\text { peradilan }\end{array}$ & 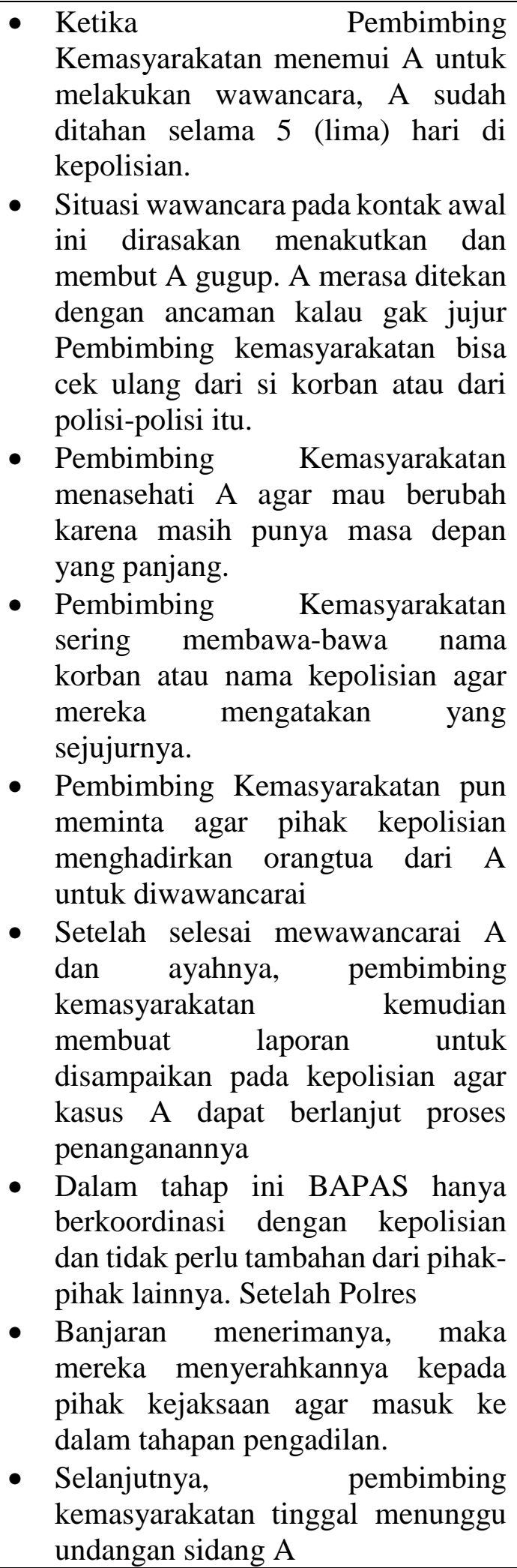 & $\begin{array}{l}\text { - B sudah ditahan selama } 2 \text { (dua) } \\
\text { hari oleh pihak kepolisian ketika } \\
\text { bertemu dengan Pembimbing } \\
\text { Kemasyarakatan } \\
\text { - Selama ditahan, B mengaku tidak } \\
\text { mendapatkan kekerasan dan ia } \\
\text { digabungkan di dalam sel anak } \\
\text { perempuan lainnya. } \\
\text { - Selama proses diwawancarai } \\
\text { oleh Pembimbing } \\
\text { Kemasyarakatan, B selalu } \\
\text { didampingi oleh Ayahnya. }\end{array}$ \\
\hline
\end{tabular}




\begin{tabular}{|c|c|c|c|c|}
\hline $\begin{array}{c}\text { 118SHARE: SOCIAL WORK } \\
\text { JURNAL }\end{array}$ & VOLUME: 7 & NOMOR: 1 & HALAMAN: $1-129$ & $\begin{array}{l}\text { ISSN:2339-0042 }(p) \\
\text { ISSN: } 2528-1577 \\
(e)\end{array}$ \\
\hline
\end{tabular}

\begin{tabular}{|c|c|c|}
\hline $\begin{array}{l}\text { Saat } \\
\text { pengadilan }\end{array}$ & 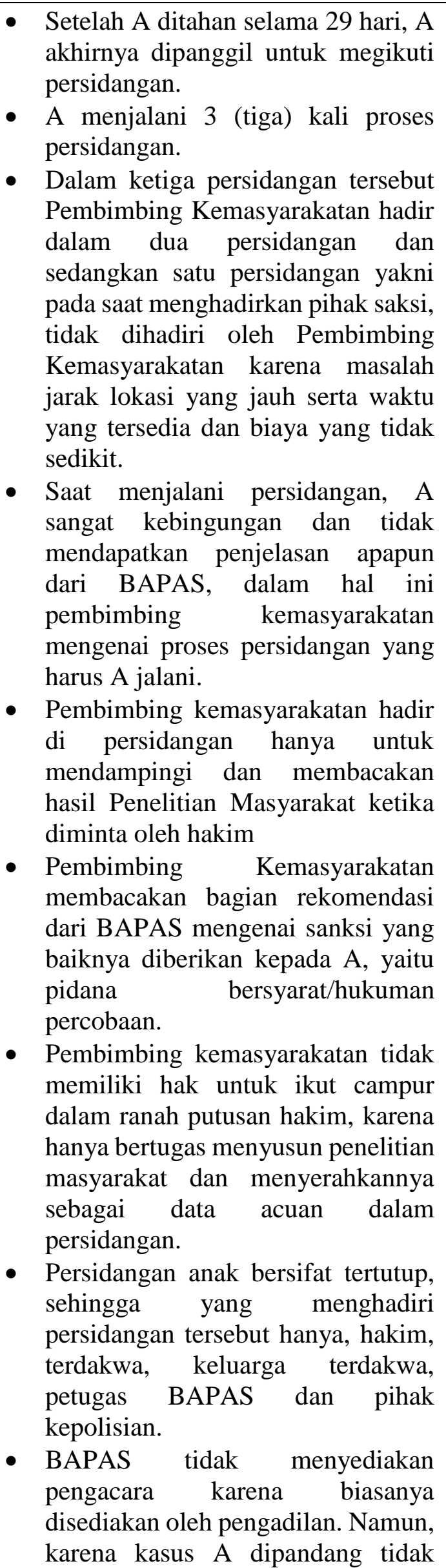 & $\begin{array}{l}\text { - Persidangan B digelar setelah B } \\
\text { ditahan selama } 2 \text { (dua) minggu } \\
\text { oleh pihak kepolisian. } \\
\text { - B menjalani } 8 \text { (delapan) proses } \\
\text { persidangan dan Pembimbing } \\
\text { Kemasyarakatan tidak } \\
\text { menghadiri seluruh proses } \\
\text { persidangan tersebut, sehingga B } \\
\text { dan keluarganya merasa tidak } \\
\text { diperhatikan dan dibantu. } \\
\text { Dalam kedelapan persidangan, B } \\
\text { menghadirinya dengan ditemani } \\
\text { oleh orang tuanya dan pengacara } \\
\text { anak yang disediakan oleh pihak } \\
\text { pengadilan anak. } \\
\text { B terlibat dalam kasus yang berat, } \\
\text { sehingga pihak pengadilan } \\
\text { menyediakan pengacara untuk } \\
\text { mendampingi B dalam } \\
\text { persidangan. } \\
\text { Selama proses persidangan, B } \\
\text { merasa terbantu dengan } \\
\text { kehadiran pengacara, namun } \\
\text { tidak mendapatkan bantuan yang } \\
\text { berpengaruh signifikan dari } \\
\text { Pembimbing Kemasyarakatan. } \\
\text { Pada saat penetapan sanksi bagi } \\
\text { B, hakim tidak menyetujui } \\
\text { rekomendasi BAPAS yaitu } \\
\text { Pidana Bersyarat. } \\
\text { Hakim menetapkan sanksi } \\
\text { Pidana Penjara selama } 2 \text { tahun } 2 \\
\text { bulan di } \\
\text { Pemasyarakatan. } \\
\text { Pengacara B menajukan banding, } \\
\text { sehingga Pidana Penjara bagi B } \\
\text { berkurang menjadi } 1 \text { tahun. }\end{array}$ \\
\hline
\end{tabular}




\begin{tabular}{|c|c|c|c|c|}
\hline $\begin{array}{c}\text { 118SHARE: SOCIAL WORK } \\
\text { JURNAL }\end{array}$ & VOLUME: 7 & NOMOR: 1 & HALAMAN: $1-129$ & $\begin{array}{l}\text { ISSN:2339 -0042 }(p) \\
\text { ISSN: 2528-1577 }(e)\end{array}$ \\
\hline
\end{tabular}

\begin{tabular}{|c|c|c|}
\hline & $\begin{array}{l}\text { berat, maka A tidak didampingi oleh } \\
\text { pengacara. } \\
\text { - Pada sidang ketiga, hakim } \\
\text { menetapkan sanksi bagi A yaitu } \\
\text { sanksi pidana penjara di Lembaga } \\
\text { Pemasyarakatan selama } 9 \text { bulan. } \\
\text { - Dalam putusannya, hakim tidak } \\
\text { menyetujui saran dari BAPAS } \\
\text { - Setelah dijatuhkan sanksi, A } \\
\text { berstatus sebagai anak Negara dan } \\
\text { tidak lagi menjadi tanggung jawab } \\
\text { BAPAS Kelas I Bandung. }\end{array}$ & \\
\hline $\begin{array}{l}\text { Setelah } \\
\text { pengadilan }\end{array}$ & $\begin{array}{l}\text { - Selama menjalani masa tahanan } \\
\text { disana, A berkelakuan baik dan } \\
\text { memenuhi syarat untuk } \\
\text { mendapatkan Program Cuti } \\
\text { Bersyarat (CB) dan mendapatkan } \\
\text { bimbingan serta pengawasan dari } \\
\text { BAPAS. } \\
\text { - A menjalani } 3 \text { (tiga) bulan di } \\
\text { Lembaga Pemasyarakatan dan sisa } 6 \\
\text { (enam) bulan dari masa tahanannya, } \\
\text { ia jalani dengan masa Cuti } \\
\text { Bersyarat. } \\
\text { - Selama masa Cuti Bersyarat (CB) } \\
\text { dan A kembali menjadi tanggung } \\
\text { jawab BAPAS. } \\
\text { A rajin memberikan laporan kepada } \\
\text { BAPAS selama masa Cuti } \\
\text { Bersyarat, yakni setiap } 2 \text { minggu } \\
\text { sekali. } \\
\text { A mendapatkan bimbingan } \\
\text { kelompok dari BAPAS sebanyak } 3 \\
\text { kali, namun A merasa prosesnya } \\
\text { sama saja dengan bimbingan } \\
\text { individu. } \\
\text { A pernah mengikuti Bimbingan } \\
\text { Kerja bagi mantan narapidana yang } \\
\text { diadakan oleh BAPAS yang bekerja } \\
\text { sama dengan Pemerintahan Jawa } \\
\text { Barat selama } 2 \text { (dua) kali. } \\
\text { - Setelah masa Cuti Bersyarat A } \\
\text { berakhir, orang tua A meminta } \\
\text { BAPAS memberikan bimbingan } \\
\text { lanjutan (after care). Kemudian } \\
\text { BAPAS membantu memberikan } \\
\text { rujukan bagi A mengikuti program } \\
\text { pembinaan di Panti Sosial Asuhan } \\
\text { Anak (PSAA) Tunas Melati }\end{array}$ & 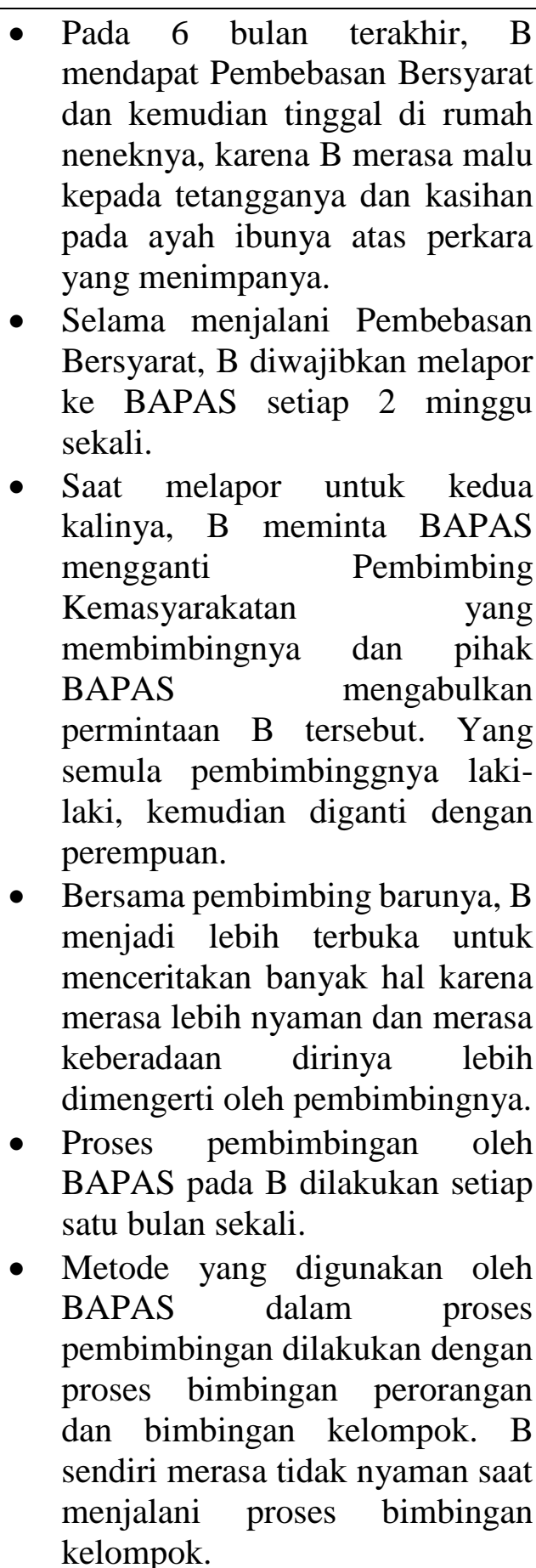 \\
\hline
\end{tabular}




\begin{tabular}{|l|l|l|}
\hline & $\begin{array}{l}\text { Bandung agar A dapat melanjutkan } \\
\text { sekolahnya kembali di SMA. }\end{array}$ & $\begin{array}{l}\text { B pun mendapatkan bimbingan } \\
\text { keterampilan dari BAPAS, } \\
\text { berupa bimbingan membaca Al- } \\
\text { Qur'an dan mengajarkan proses } \\
\text { pembuatan telor asin }\end{array}$ \\
\hline
\end{tabular}

Sumber: Hasil Penelitian, 2015

Berdasarkan hasil kajian literatur, Pembimbing Kemasyarakatan harus mendampingi anak yang berkonflik dengan hukum sejak anak ditangkap oleh pihak kepolisian agar mereka mengetahui hak-hak anak yang berkonflik dengan hukum diperhatikan atau tidak (Dubois, 2010: 302). Dalam praktiknya, hal tersebut tidak tampak pada penanganan yang diberikan oleh Pembimbing Kemasyarakatan dalam kasus A dan B. Dari hasil kajian lapangan yang dilakukan oleh peneliti terlihat bahwa Pembimbing Kemasyarakatan tidak mendampingi anak yang berkonflik dengan hukum selama proses penyidikan. Kedua anak yang diangkat menjadi kasus dalam penelitian ini sudah terlebih dahulu di sidik oleh pihak kepolisian sebelum Pembimbing Kemasyarakatan tiba untuk mendampingi anak yang berkonflik dengan hukum tersebut. Bahkan ketika terjadi tindakan kekerasan terhadap anak berkonflik dengan hukum pun, anak tidak mendapatkan perhatian dari Pembimbing Kemasyarakatan. Hal ini tidak sejalan dengan peran yang seharusnya dilakukan oleh pendamping $\mathrm{ABH}$, yaitu bahwa pekerja sosial harus mampu melindungi anak yang berkonflik dengan hukum ${ }^{40}$.

Hal lain yang penting untuk dilakukan dalam penangan $\mathrm{ABH}$ adalah perlu melibatkan keluarga dari anak yang berkonflik dengan hukum agar mereka ikut serta dalam proses hukum yang di jalani anak yang berkonflik dengan hukum. ${ }^{41}$ Dalam penanganan kasus A dan B, Pembimbing Kemasyarakatan telah melibatkan orang tua mereka. Namun, tidak

\footnotetext{
40 Stephen Hardy, Law For Social Workers (Great Britain: Cavendish Publishing limited, 1997), p. 147

${ }^{41}$ Ibid. p. 147
}

melibatkan teman-temannya atau pihak keluarga lainnya. Keikutsertaan keluarga anak yang berkonflik dengan hukum dipandang kurang maksimal karena hanya berfokus kepada kedua orang tua dari anak saja dan tidak melihat kerabat-kerabat lain yang memiliki hubungan pribadi dengan anak. Hal ini didasarkan kepada lima asumsi dasar dalam Casework yang salah satu dari poin tersebut menyebutkan bahwa tidak selamanya anak yang berkonflik dengan hukum melakukan pelanggaran karena pribadinya yang menyimpang, karena dapat juga disebabkan oleh pengaruh keluarga dan pengaruh lingkungan sekitarnya. ${ }^{42}$

Dalam proses wawancara yang dilakukan oleh Pembimbing Kemasyarakatan, pihak anak merasa tidak nyaman, sehingga anak terkesan cenderung tidak berkata jujur. Situasi demikian didorong oleh situasi Pembimbing Kemasyarakatan yang memiliki keterbatasan waktu untuk melakukan proses wawancara yaitu hanya dilakukan dalam beberapa jam saja dan harus langsung menyusun laporan penelitian kemasyarakatan, yaitu hanya dalam jangka waktu satu hari. Adanya ketersediaan waktu yang memadai merupakan hal yang penting mengingat bahwa hubungan yang terjalin antara anak yang berkonflik dengan hukum dengan pembimbingnya dalam kurun waktu tertentu, akan membuat anak yang berkonflik dengan hukum merasa diterima dan dimengerti oleh anak yang berkonflik dengan hukum akan dengan mudah mengekspresikan dirinya. ${ }^{43}$

42 Swati Sharma, BSWE 002: Interventions with individuals and groups. (Delhi: Neeraj Book, 2001) 43 ibid 
Anak yang berkonflik dengan hukum perlu memahami situasi yang sedang terjadi terhadap dirinya. Kemampuan pembimbingan untuk memberikan informasi yang selengakaplengkapnya mengenai proses yang sedang dijalani dan proses-proses selanjutnya kepada anak sangatlah penting. ${ }^{44}$ Namun, dalam praktiknya hal ini tidak terjadi dalam kasus $\mathrm{A}$ dan B, di mana kedua anak tersebut merasakan ketakutan dan mengalami kebingungan selama menjalani proses hukum mereka. Pembimbing kemasyarakatan tidak memberikan informasi yang memadai untuk memberikan gambaran situasi dan proses hukum mereka. Kondisi tersebut menjadi salah satu keterbatasan yang terjadi pada pembimbing kemasyarakatan.

Berbagai keterbatasan yang dialami oleh Pembimbing Kemasyarakatan dalam melakukan proses penelitian masyarakat dalam kasus A dan B tersebut disebabkan oleh beberapa alasan seperti yang diungkapkan oleh Pembimbing Kemasyarakatan sebagai berikut: jarak yang harus ditempuh oleh Pembimbing Kemasyarakatan untuk menjangkau lokasi tempat tinggal anak yang berkonflik dengan hukum terlalu jauh, dalam hari yang bersamaan Pembimbing Kemasyarakatan harus mendampingi beberapa anak yang berkonflik dengan hukum pada lokasi yang berbeda, keterbatasan jumlah Pembimbing Kemasyarakatan yang ada dan bekerja di BAPAS, sempitnya waktu yang dimiliki oleh Pembimbing Kemasyarakatan untuk melakukan proses penelitian masyarakat dan menyusun laporan tersebut. Oleh sebab itulah penelitian masyarakat yang dilakukan oleh Pembimbing Kemasyarakatan, khususnya dalam kasus A dan B dirasa belum maksimal.

\section{Simpulan}

Sebagai lembaga yang diberikan kewenangan untuk mengawal sistem peradilan anak yang berbeda dengan perlakuan hukum terhadap orang dewasa, BAPAS sudah menjalankan fungsi sesuai dengan proses yang ditetapkan. Namun pelaksanaannya fungsi BAPAS

\footnotetext{
${ }^{44}$ Dr. Stephen Hardy, Law For Social Workers. (Great Britain: Cavendish Publishing limited, 1997)
}

tersebut belum berjalan optimal sebagaimana yang diharapkan yang diantaranya terkait dengan pelaksanaan peran dari Pembimbing Kemasyarakatan sebagai perangkat BAPAS. Pada tahap sebelum pengadilan, pelayanan terhadap $\mathrm{ABH}$ belum terlaksana secara maksimal oleh para pembimbing kemasyarakatan,dimana masih ada hak-hak $\mathrm{ABH}$ yang belum terpenuhi. Untuk pada masa pengadilan, pelayanan pembimbing kemasyarakatan sudah terlaksana dengan baik namun belum optimal, terutama dalam hal informasi mengenai proses persidangan, $\mathrm{ABH}$ kurang mendapatkan informasi yang dibutuhkan sehingga berada kondisi tertekan dalam menjalani persidangan. Untuk pada masa setelah pengadilan peran Pembimbing Kemasyarakat dan fungsi BAPAS belum dilaksanakan secara maksimal, terutama dalam pelayanan konseling dan bimbingan ketrampilan juga belum mempertimbangkan secara spesifik kebutuhan $\mathrm{ABH}$ untuk masa depannya.

Untuk meningkatkan fungsi BAPAS dan peran dari Pembimbing Kemasyarakat selanjutnya upaya yang dapat dilakukan antara lain dengan penambahan Pembimbing Kemasyarakatan agar kasus-kasus anak yang berkonflik dengan hukum tidak banyak yang terbengkalai. Hal ini harus disertai pula dengan menjaga intensitas komunikasi yang rutin antara Pembimbing dengan $\mathrm{ABH}$ dalam menjalankan proses pelayanan yang semestinya. Selain itu, perlu adanya pelayanan yang diberikan kepada orang tua dari anak yang berkonflik dengan hukum agar orang tua juga mampu membantu anak yang berkonflik dengan hukum kembali ke tengah-tengah masyarakat.

\section{Daftar Pustaka}

Bartolla, Clemens. 1985. Juenile delinquency. University of Northern lowa USA. Allyn and Bacon fourth edition. 


\begin{tabular}{|c|c|c|c|c|}
\hline $\begin{array}{c}\text { 118SHARE: SOCIAL WORK } \\
\text { JURNAL }\end{array}$ & VOLUME: 7 & NOMOR: 1 & HALAMAN: $1-129$ & $\begin{array}{l}\text { ISSN:2339 -0042 (p) } \\
\text { ISSN: 2528-1577 }(e)\end{array}$ \\
\hline
\end{tabular}

DuBois, B. \& Miley, K. (2010). Social Work: An Empowering Profession 6th ed. Boston: Pearson Education.

Hardy, Dr. Stephen. 1997. Law For Social Workers. Great Britain: Cavendish Publishing limited.

Marlina, 2009. Peradilan Pidana Anak di Indonesia Pengembangan Konsep Diversi dan Restorative Justice. Bandung: Refika Aditama.

Nashriana. 2012. Perlindungan Hukum Pidana Bagi Anak Di Indonesia. Depok: RajaGrafindo Persada

Raharjo, ST. 2015. "Pekerjaan Sosial Generalis, Suatu Pengantar Bekerja Bersama Organisasi dan Komunitas", Edisi Revisi Buku, Unpad Press,

Raharjo, ST. 2015. "Dasar Pengetahuan Pekerjaan Sosial”, Buku, Unpad Press

Raharjo, ST., Taftazani, BM., Apsari, NC., Santoso, MB. 2016. "PANDUAN PRAKTIKUM MIKRO (Konseling dan Pengembangan Diri)". Buku . Unpad Press.

Raharjo, ST. 2015. "Assessment dan Wawancara dalam Prakti Pekerjaan Sosial dan Kesejahteraan Sosial", Edisi Revisi Buku, Unpad Press

Supeno, Hadi. 2010. Kriminalisasi Anak: Tawaran Gagasan Radikal Peradilan Anak Tanpa Pemidanaan. Jakarta: Gramedia Pustaka Umum.

Sambas, Dr. Nandang. 2013. Peradilan Pidana Anak di Indonesia dan Instrumen Internasional Perlindungan Anak serta Penerapannya. Yogyakarta: Graha Ilmu

Sharma, Swati. 2001. BSWE O02: Interventions with individuals and groups. Delhi: Neeraj Book

Sugiyono. 2009. Metode penelitian Kualitatif. Bandung: Alfabeta.
Surakhmad, Winarno. 1998. Pengantar Penelitian Ilmiah: Dasar Metode Teknik. Bandung:Tarsito.

Undang-Undang Nomor 11Tahun 2012 Tentang Sistem Peradilan Pidana Anak 